\title{
Tunas off northwest Africa: The epipelagic diet of The Bigeye and Skipjack tunas
}

\author{
Joana Romero $^{\text {a, } *}$, Paulo Catry ${ }^{\mathrm{b}}$, Margarida Hermida ${ }^{\mathrm{c}, \mathrm{d}, 1}$, Verónica Neves ${ }^{\mathrm{e}}$, \\ Bárbara Cavaleiro $^{c, d, f}$, Lídia Gouveia ${ }^{g}$, José Pedro Granadeiro ${ }^{a}$ \\ ${ }^{a}$ CESAM - Centre for Environmental and Marine Studies, Departamento de Biologia Animal, Faculdade de Ciências da Universidade de Lisboa, Campo Grande, $1749-016$ \\ Lisbon, Portugal \\ ${ }^{\mathrm{b}}$ MARE - Marine and Environmental Sciences Centre, ISPA-Instituto Universitário, Rua Jardim do Tabaco, 1149-041, Lisbon, Portugal \\ ${ }^{\mathrm{c}}$ MARE - Marine and Environmental Sciences Centre, Agência Regional para o Desenvolvimento da Investigação Tecnologia e Inovação (ARDITI), Edifício Madeira \\ Tecnopolo, Caminho da Penteada, 9020-105, Funchal, Madeira, Portugal \\ d Oceanic Observatory of Madeira, Agência Regional para o Desenvolvimento da Investigação Tecnologia e Inovação (ARDITI), Edifício Madeira Tecnopolo, Caminho da \\ Penteada, 9020-105, Funchal, Madeira, Portugal \\ e IMAR/Okeanos, Department of Oceanography and Fisheries, University of the Azores, 9901-862 Horta, Azores, Portugal \\ ${ }^{\mathrm{f}}$ Direção Regional do Mar, Secretaria Regional de Mar e Pescas, Avenida do Mar e das Comunidades Madeirenses, $n^{\circ} 23$ - $9000-054$ Funchal, Portugal \\ ${ }^{\mathrm{g}}$ DSEIMar, Direção de Serviços de Monitorização, Estudos e Investigação do Mar, Avenida do Mar e das Comunidades Madeirenses, $231^{\circ}$ Esq, $9000-054$, Funchal, \\ Madeira, Portugal
}

\section{A R T I C L E I N F O}

\section{Handled by Steven X. Cadrin}

\section{Keywords:}

Thunnus obesus

Katsuwonus pelamis

Diet

Mercury

Northeast Atlantic Ocean

\begin{abstract}
A B S T R A C T
Tunas are among the most exploited top predators worldwide, with negative impacts on some of their stocks. Changes in their population abundance can impact marine food-webs and have the potential to alter entire ecosystems. To better understand the impacts of the exploitation of tuna stocks in the most critical habitats, basic knowledge on the diet of these species in each region is required. Here, we describe the diet of the two most fished tuna species in the archipelago of Madeira, the Bigeye tuna Thunnus obesus and the Skipjack tuna Katsuwonus pelamis, based on stomach contents analysis. To gain further insights into the diet, and also better assess the possible bias caused by the occurrence of live bait in stomachs, we compared tuna mercury values with those of two other predators with similar diets that are not directly targeted by fisheries, and with Bigeye and Skipjack tunas from other ocean basins. Bigeye tunas fed mostly on Atlantic chub mackerel Scomber colias and mackerel Trachurus sp., which together contributed with $85 \%$ of total prey weight. Only $7.5 \%$ of prey weight was constituted by mesopelagic prey, including myctophids and cephalopods. Skipjack tunas had an epipelagic diet ( $\mathrm{NF}=97 \%$ ), with the Atlantic chub mackerel representing half of the total prey weight, despite Longspine snipefish Macroramphosus scolopax and Sand smelt Atherina sp. accounting for $62.9 \%$ of the total number of prey. There were interannual variations in diet likely linked to interannual pelagic community shifts. Bait did not bias the results of the stomach analysis of these tunas and bait species were observed to be part of the natural diet of both tuna species. Baseline data provided by this study should allow for more informed decisions for an efficient ecosystem-based fisheries management.
\end{abstract}

\section{Introduction}

Marine top predators are among the most threatened functional groups in the ocean, and tunas are one of the most targeted by the fishery industry. In 2018, around 5.2 million tonnes of commercial tunas were landed worldwide (ISSF, 2017), reaching up to 7.9 million tonnes when including all tuna and tuna-like species (ca. 9\% of global total marine catches) (FAO, 2020). In the Atlantic Ocean, an average of half a million tonnes of tunas are captured per year (2000-2018; ICCAT, 2020). Such pressure has led to the depletion of some stocks, such as the Bigeye tuna,

\footnotetext{
* Corresponding author at: CESAM - Centre for Environmental and Marine Studies, Departamento de Biologia Animal, Faculdade de Ciências da Universidade de Lisboa, Campo Grande, 1749-016, Lisbon, Portugal.

E-mail address: j-romero@live.com (J. Romero).

1 Current Address: University of Bristol, Senate House, Tyndall Ave, Bristol, United Kingdom.
} 
which is currently considered overfished in the Atlantic Ocean (ISSF, 2017). The decline of top predators impacts the structure of communities and the diversity of food webs, as well as the productivity and connectivity of the ecosystems (Doney et al., 2012). Impacts are not only observed directly on their prey but can produce cascading effects on other marine species and communities. For example, the increase in tuna fishing activity in the 1960's in the eastern tropical Atlantic Ocean and the consequent decline of tuna populations in that area is thought to have caused a shift in the diet and a dramatic decline of the once massive Sooty tern Onychoprion fuscatus population of Ascension island which depends on interactions with sub-surface predators to locate and catch prey (Reynolds et al., 2019).

The Bigeye tuna Thunnus obesus and the Skipjack tuna Katsuwonus pelamis are the main targeted tuna species around the archipelago of Madeira (Gouveia et al., 2019), located in the subtropical NE Atlantic Ocean. In this archipelago there is a strong tuna fishing tradition taking place mostly from March to October (Gouveia and Mejuto, 2003). Here tunas are caught mostly using pole-and-line, which uses small pelagic fish as live bait. In Madeira, an average of 1667 ( \pm 481 SD) and 549 $( \pm 461 \mathrm{SD})$ tonnes of Bigeye and Skipjack tuna, respectively, are landed every year (2007-2017; Gouveia et al., 2019), comprising an average of $35 \%$ of local fisheries landings and even reaching $50 \%$ in some years (Hermida and Delgado, 2016). Contrary to the Bigeye tuna stock assessment, the Eastern Atlantic Skipjack tuna stock is not considered overfished, even though it accounts for nearly $50 \%$ of the catches in weight in the Atlantic Ocean (ISSF, 2017).

Despite the considerable economic importance of tunas in the subtropical and temperate NE Atlantic, more specifically in Madeira, Azores and the Canary Islands, few ecological studies on these species have been conducted in this region. This contrasts with the various studies conducted in the Pacific on their distribution (eg. Houssard et al., 2019; Lehodey et al., 1997), movements (eg. Schaefer et al., 2009), reproduction (eg. Hunter et al., 1986), and contamination (eg. Chen et al., 2014), and also in the South and NW Atlantic (Matthews et al., 1977; Matsumoto and Miyabe, 2002; da Silva et al., 2019). Large knowledge gaps on the ecology of these species remain in the Atlantic, such as migratory routes, spawning periods and foraging ecology. According to our literature search, only a single study on the foraging ecology of Skipjack tuna was conducted around the Canary Islands (Ramos et al., 1995), with no records for Bigeye tuna.

Tunas are opportunistic predators which means that their main prey shift according to region, reflecting prey availability in the different ocean compartments (Ménard et al., 2006; Gorni, 2016; Ohshimo et al., 2018). Therefore, knowledge on their diet will contribute to our understanding of food web dynamics and allow to infer broad community-scale changes in the abundance, availability, and diversity of poorly known mid-trophic prey. Such knowledge is required for ecosystem-based fisheries management and the conservation of large pelagic predators, including tunas.

Analysis of stomach contents is a direct and reliable way to assess the diet of tunas (eg. Glaser et al., 2015; Varela et al., 2019). However, the use of live bait during fishing events may raise concerns about what proportion of stomach content is bait. Indirect techniques, like determination of mercury concentration in tissues have allowed researchers to infer the diet of several predators for which sampling stomach contents is difficult (Layman et al., 2012; Teffer et al., 2014). Mercury concentrations can help distinguish between a mesopelagic/bathypelagic diet and an epipelagic one, as deep-ocean species have significantly higher concentrations of mercury than epipelagic species due to the higher rate of microbial mediated methylation of mercury in sub-thermocline low oxygen waters (Choy et al., 2009).

This study describes the diet of two important top predators, the Bigeye and the Skipjack tunas, in the pelagic region around the archipelago of Madeira, using stomach content analysis. To control for potential biases due to the use of live bait in this fishery, we also determined the mercury concentration in tissues of these two tunas and of two other abundant pelagic predators from the region with epipelagic diets, the Yellowmouth barracuda Sphyraena viridensis and the Longfin yellowtail Seriola rivoliana. Further comparisons of mercury concentrations with tunas from other ocean basins were also done.

\section{Methods}

\subsection{Tuna sampling}

Seventy-one bigeye and 61 Skipjack tuna stomachs collected from 16 and 10 fishing events, respectively, were obtained directly from local fishermen. The average fork length of Bigeye tunas was $77.0 \pm 26.1 \mathrm{~cm}$ $(60-170 \mathrm{~cm})$ and of Skipjack tunas was $50.1 \pm 3.8 \mathrm{~cm}(42.6-59.3 \mathrm{~cm})$. Fish were captured using pole-and-line fishing vessels in Madeira island in 2016/2017 and 2016-2018 for Bigeye and Skipjack tuna, respectively. Stomachs were removed and kept frozen until sorting in the laboratory. A sample of blood from the branchial arches was also collected for analysis of mercury concentration, and frozen until further processing in the laboratory.

Coordinates from 22 tuna fishing events that took place in September 2017 and May-October 2018 were obtained from local fishermen (Fig. 1).

\subsection{Prey identification}

Once in the laboratory, stomachs were thawed, and the contents carefully removed and classified according to digestive state and taxonomic group (fish, cephalopods, crustaceans). Digestion levels for fish and cephalopods were attributed according to Aloncle and Delaporte (1974) and Alonso et al. (2018), respectively (Supplementary Material, Table A.1). Whenever the digestion level corresponded to I or II, fish prey were weighed $( \pm 0.1 \mathrm{~g})$, measured $( \pm 0.1 \mathrm{~cm}$, fork length) and identified to the lowest taxonomic level possible (family, genus, species) using morphologic characteristics (Whitehead et al., 1989). Individuals with digestion levels of III or higher were identified using our reference collection of fish skeletons and otoliths from the NE Atlantic (currently comprising over 700 specimens of ca. 100 species). Specific vertebrae were measured in order to obtain size estimations and weights of each individual (Granadeiro and Silva, 2000). When identification using hard structures was not possible, a small piece of muscle was collected for DNA barcoding analysis. Cephalopods were identified to the lowest taxonomic level possible (family, genus, species) based on morphology guides of the lower beak (Clarke, 1986; Lu and Ickeringill, 2002) and DNA-barcoding analysis. Beaks with no tissue attached were excluded from the quantitative analysis due to the impossibility of knowing for how long they had been in the stomach. This way we avoid over-representation of cephalopod prey in the tuna's diet. The number of individuals in a sample was estimated by counting all identifiable structures and only considering the one which represented the highest number of individuals of each species. The Blue jack mackerel is the most common species of the genus Trachurus to be found in this marine region. However, due to the similarities of vertebrae between Trachurus picturatus and Trachurus trachurus and inability to confirm the exact species, we refer to this genus as Trachurus sp..

Tissues of 21 fish, 23 cephalopods and 6 crustaceans were sampled from stomach contents of Bigeye tuna and Skipjack tuna from which DNA was extracted using the E.Z.N.A. Tissue DNA kit (Omega Bio-tek). Optimized PCR conditions were used to amplify the 3' end region of the 16S rRNA gene of each prey DNA using the universal primers 16Sar and 16SSbr of Palumbi (1996) (Alonso et al., 2014). Both directions of the PCR products were sequenced in outsourcing (Macrogen Inc.). The resulting sequences were queried using BLAST (NCBI) and searches with similarity values higher than $98 \%$ were considered as positive identifications. 


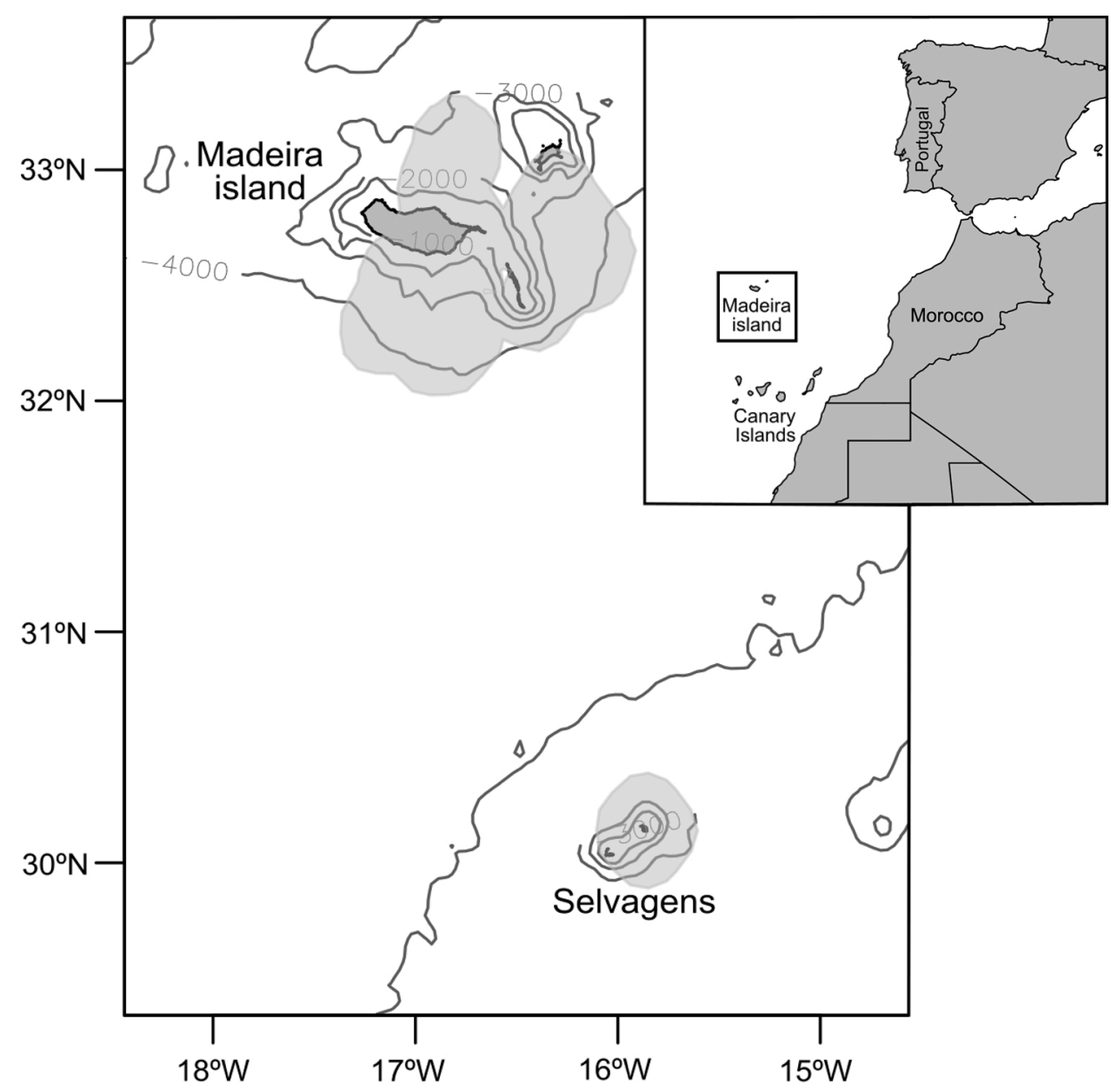

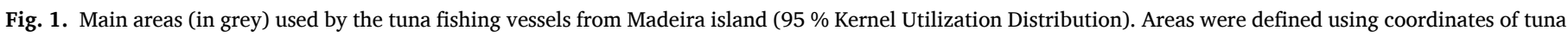
fishing events in September 2017 and May-October 2018, as provided by fishermen ( $=22)$. Isobathic lines of 1000, 2000, 3000, 4000m.

\subsection{Diet characterization}

The diets of Bigeye and the Skipjack tuna were characterized using numeric frequency (NF, number of individuals of a species in relation to the total number of individuals found in the stomachs), frequency of occurrence (FO, number of stomachs in which a specific prey was found in relation to the total number of stomachs analysed), and prey weight percentage $(\mathrm{W}$, sum of weights of a species in relation to the total weight of individuals found in the stomach contents). Not all individuals had length or weight measurements available due to the high digestion level or missing hard parts. Thus, we calculated the average weight of species using individuals with weight data and assumed it to be the weight of the rest of the individuals of that species. Still, for some prey species we did not have any information on their weight and so, we excluded them from this analysis. We do not feel that the exclusion of these species would significantly influence the analysis, since most of these prey rarely appeared in the stomach contents, and the overall description of the diet would remain the same. The Shannon-Wiener diversity index was used to calculate the prey diversity found in the stomachs of the two tuna species. Ontogenetic differences in the diet of Bigeye tunas were assessed using Permutational multivariate analysis of variance (PERMANOVA). Bigeye tunas were divided into three length classes: 60-80 $(\mathrm{n}=40), 80-100(\mathrm{n}=12)$ and $>100 \mathrm{~cm}(\mathrm{n}=16)$, corresponding approximately to one, two and more than three years old, according to Zhu et al. (2009). Bigeye tunas with more than $100 \mathrm{~cm}$ are considered mature individuals. It was not possible to measure the length of one of the tunas.

\subsubsection{Bait}

In Madeira, the Bigeye tuna fishery involves the use of live bait, particularly Atlantic chub mackerel Scomber colias and Blue jack mackerel Trachurus picturatus, to attract tunas to the surface. On the other hand, Skipjack tuna fisheries use European pilchard Sardina pilchardus, Sand smelt Atherina sp. or Bogue Boops boops, and when abundant, Longspine snipefish Macroramphosus scolopax.

Live bait is considered to potentially bias foraging ecology studies due to difficulties distinguishing it from the natural diet (Ankenbrandt, 1985; Ramos et al., 1995). To address this issue, we (1) compared mercury concentrations in the tissues of the tunas studied with two other local predatory fishes known to have an epipelagic diet: Yellowmouth barracuda Sphyraena viridensis and Longfin yellowtail Seriola rivoliana, and with Bigeye and Skipjack tunas from other ocean basis which have a mesopelagic and an epipelagic diet, respectively. A comparison with other epipelagic and mesopelagic predator fishes will help to address if the diets of the Bigeye and Skipjack tunas in the archipelago of Madeira are closer to epipelagic or mesopelagic diets. We also (2) excluded the bait (species known to be used as bait and with digestion levels I and II) from the original stomach content dataset and compared it with the diet inferred from the complete stomach content dataset (NF, FO, and W) (Ankenbrandt, 1985; Ramos et al., 1995).

Muscle samples of Yellowmouth barracuda and Longfin yellowtail were obtained from commercial fisheries in Madeira island and from a seizure of illegal fishing in the Selvagens islands, respectively. Each individual was measured $( \pm 1 \mathrm{~cm})$ and weighted $( \pm 1 \mathrm{~g})$ upon capture. White muscle was collected for measurement of mercury concentration.

Mercury concentrations were analysed using blood for the tuna 
species and muscle for the two other predators. By using the tuna's blood, we attempted to minimize the contribution of assimilated diet that would have been obtained in more distant waters used by tunas before arriving in Madeira. As it was not possible to collect blood for the two other predator species, white muscle was used instead. These predators are not known to perform long migrations like tunas (McClellan and Cummings, 1997; Fontes and Afonso, 2017), therefore, both tissues should represent the mercury values accumulated in the marine environment around the archipelago of Madeira. Because mercury accumulates differently among tissues (Storelli et al., 2005; Voegborlo et al., 2007), we also measured the concentration of mercury in the muscle of the same individuals of Bigeye tuna $(n=20)$ that we analysed for blood (Supplementary Material, Figure A.1).

The blood and muscle tissues were first lyophilized and reduced into a homogenous powder that was then used to determine the total concentration of mercury. Samples (weighing 3-17 $\mathrm{mg}$ ) were analysed using thermal decomposition atomic absorption spectrometry alongside gold amalgamation in LECO AMA-254 equipment. A maximum coefficient of variation of $10 \%$ was defined for a minimum of 2 mercury readings (Furtado et al., 2019). Tort- 2 and Tort- 3 were used as the certified reference material to support the precision of the method (muscle tissue, certified value of $0.27 \pm 0.06 \mathrm{mg} \mathrm{kg}^{-1}$ and $0.292 \pm 0.22$ $\mathrm{mg} \mathrm{kg}{ }^{-1}$, respectively). The recovery efficiency for Tort 2 was $82.2 \pm$ $0.8 \%(n=6)$, and for Tort 3 was $84.4 \pm 2.4 \%(n=8)$. Mercury concentrations are reported on a dry weight basis (dw).

All statistical analyses were performed using $\mathrm{R}$ version 4.0.2 (R Core Team, 2020).

\section{Results}

\subsection{Bigeye tuna diet}

A total of 762 prey items were found in 69 stomachs of Bigeye tuna (2 stomachs were empty), of which $95 \%$ were identified to family, genus or species level, resulting in 24 species, 23 genus and 20 different families. Teleost fish were the most consumed prey, followed by cephalopods (Table 1). The Bigeye tuna presented an epipelagic diet $(\mathrm{NF}=84 \%$ and $\mathrm{W}=92 \%)$ with only $9 \%(\mathrm{~W}=7.5 \%)$ of the prey belonging to mesopelagic layers. The Atlantic chub mackerel was the most consumed species overall ( $\mathrm{NF}=41.1 \%$ and $\mathrm{W}=48.8 \%$ ), followed by mackerel Trachurus sp. $(\mathrm{NF}=25.7 \%$ and $\mathrm{W}=36.4 \%)$ and Longspine snipefish $(\mathrm{NF}=10.6 \%$ and $\mathrm{FO}=14.5 \%$ ) although it only represented $2.2 \%$ of prey weight. Only the Bogue Boops boops and the Long snouted lancetfish Alepisaurus ferox contributed with more weight to the diet than the Longspine snipefish,

Table 1

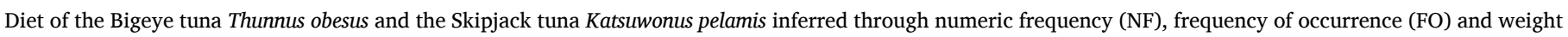
percentage (W). Depth refers to the layer occupied by the prey. Numbers between brackets represent the sample size.

\begin{tabular}{|c|c|c|c|c|c|c|c|c|c|}
\hline \multirow[t]{2}{*}{ Taxa } & \multirow[t]{2}{*}{ Family } & \multirow[t]{2}{*}{ Species } & \multirow[b]{2}{*}{ Depth } & \multicolumn{2}{|l|}{ Bigeye } & \multirow[b]{2}{*}{ W } & \multicolumn{2}{|l|}{ Skipjack } & \multirow[b]{2}{*}{$\mathrm{W}$} \\
\hline & & & & NF (762) & FO (69) & & NF (550) & FO (57) & \\
\hline \multirow[t]{26}{*}{ Teleostei } & & & & 92.7 & 98.6 & - & 97.8 & 100 & - \\
\hline & Scombridae & Scomber colias & Epipelagic & 41.1 & 69.6 & 48.8 & 14.4 & 47.4 & 49.5 \\
\hline & Carangidae & Trachurus sp. & Epipelagic & 25.7 & 69.6 & 36.4 & 4.5 & 21.1 & 12.0 \\
\hline & Centriscidae & Macroramphosus scolopax & Epipelagic & 10.6 & 14.5 & 2.2 & 35.8 & 35.0 & 11.0 \\
\hline & Atherinidae & Atherina sp. & Epipelagic & & & & 27.1 & 36.8 & 13.2 \\
\hline & Sparidae & Boops boops & Epipelagic & 1.2 & 10.1 & 2.8 & 4.5 & 14.0 & 2.5 \\
\hline & Scomberesocidae & Scomberesox saurus & Epipelagic & 0.8 & 2.9 & 1.7 & & & \\
\hline & Clupeidae & Sardina pilchardus & Epipelagic & & & & 10.4 & 22.8 & 10.9 \\
\hline & & Sardinella sp. & Epipelagic & & & & 0.2 & 1.8 & 0.4 \\
\hline & & Unidentified & Epipelagic & & & & 0.7 & 7.0 & - \\
\hline & Bramidae & Brama brama & Mesopelagic & 0.3 & 2.9 & 0.9 & & & \\
\hline & Molidae & Ranzania laevis & Epipelagic & 0.3 & 1.4 & - & & & \\
\hline & Alepisauridae & Alepisaurus ferox & Mesopelagic & 0.4 & 2.9 & 4.9 & & & \\
\hline & Paralepididae & Arctozenus risso & Mesopelagic & 1.0 & 7.2 & - & & & \\
\hline & & Sudis hyalina & Mesopelagic & 0.1 & 1.4 & - & & & \\
\hline & Trichiuridae & Unidentified & Mesopelagic & & & & 0.2 & 1.8 & - \\
\hline & Nomeidae & Cubiceps gracilis & Mesopelagic & 2.9 & 7.2 & 0.5 & & & \\
\hline & Scopelarchidae & Scopelarchus sp. & Mesopelagic & 0.3 & 1.4 & - & & & \\
\hline & Myctophidae & Diaphus sp. & Mesopelagic & 0.8 & 5.8 & 0.2 & & & \\
\hline & & Diogenichthys atlanticus & Mesopelagic & 0.1 & 1.4 & - & & & \\
\hline & & Gonichtys cocco & Mesopelagic & 0.1 & 1.4 & $<0.1$ & & & \\
\hline & & Hygophum hygomii & Mesopelagic & 0.1 & 1.4 & $<0.1$ & & & \\
\hline & & Hygophum reinhardtii & Mesopelagic & 0.3 & 1.4 & $<0.1$ & & & \\
\hline & & Hygophum taaningi & Mesopelagic & 0.4 & 1.4 & $<0.1$ & & & \\
\hline & & Hygophum sp. & Mesopelagic & 4.9 & 1.4 & 0.3 & & & \\
\hline & Unidentified fish & & & 1.3 & 8.7 & - & & & \\
\hline \multirow[t]{10}{*}{ Cephalopoda } & & & & 3.5 & 15.9 & - & 0.2 & 1.8 & - \\
\hline & Mastigoteuthidae & Mastigoteuthis sp. & Mesopelagic & 0.1 & 1.4 & - & & & \\
\hline & Ommastrephidae & Todarodes sagittatus & Mesopelagic & 0.5 & 2.9 & 0.5 & & & \\
\hline & & Ommastrephes bartramii & Epipelagic & & & & 0.2 & 1.8 & 0.4 \\
\hline & & Unidentified & & 0.5 & 5.8 & - & & & \\
\hline & Onychoteuthidae & Onychoteuthis sp. & Epipelagic & 0.5 & 2.9 & 0.2 & & & \\
\hline & Decapodiformes & Unidentified & Unknown & 0.3 & 2.9 & - & & & \\
\hline & Argonautidae & Argonauta sp. & Epipelagic & 0.3 & 2.9 & - & & & \\
\hline & Octopodidae & Unidentified & Unknown & 0.1 & 1.4 & - & & & \\
\hline & Unidentified cephalopod & & Unknown & 1.2 & 4.3 & - & & & \\
\hline \multirow[t]{5}{*}{ Arthropoda } & & & & 3.7 & 14.5 & - & 0.4 & 1.8 & - \\
\hline & Penaeidae & Funchalia villosa & Mesopelagic & 0.3 & 2.9 & - & & & \\
\hline & Decapoda & Unidentified & Unknown & 1.0 & 1.4 & - & & & \\
\hline & Platyscelidae & Platyscelus sp. & Unknown & 1.3 & 1.4 & - & & & \\
\hline & Unidentified crustacean & & Unknown & 1.0 & 11.6 & - & 0.4 & 1.8 & - \\
\hline Gastropoda & & Unidentified & Unknown & & & & 1.6 & 1.8 & - \\
\hline \multirow[t]{2}{*}{ Tunicata } & & & & 0.1 & 1.4 & & & & - \\
\hline & Thaliacea & Unidentified & Unknown & 0.1 & 1.4 & & & & - \\
\hline
\end{tabular}


despite appearing in less stomachs and numbers $(\mathrm{W}=2.8 \%$ and $\mathrm{FO}=$ $10.1 \%$, and $\mathrm{W}=4.9 \%$ and $\mathrm{FO}=2.9 \%$, respectively). Few mesopelagic preys were found in the stomach contents, mostly comprising myctophids of the genus Hygophum ( $\mathrm{NF}=5.7 \%$ and $\mathrm{W}=0.4 \%$ ) and Diaphus $(\mathrm{NF}=0.8 \%$ and $\mathrm{W}=0.2 \%)$, Driftfish Cubiceps gracilis $(\mathrm{NF}=2.9 \%$ and $\mathrm{W}$ $=0.5 \%$ ), and barracudinas (Arctozenus risso with $\mathrm{NF}=1.0 \%$ and Sudis hyalina with $\mathrm{NF}=0.1 \%$ ). Cephalopods comprised $\mathrm{NF}=3.5 \%$ and $\mathrm{W}=$ $1.2 \%$ of the prey items. Other cephalopods, represented by older beaks with no remaining flesh, were also found in the stomachs of this tuna species (Supplementary Material, Table A.2). The Shannon-Wiener diversity for the Bigeye tuna was $1.79 \pm 0.14(n=69)$.

The importance of the main prey of the Bigeye tuna changed slightly between 2016 and 2017, with Atlantic chub mackerel decreasing its importance from 2016 to $2017(\mathrm{NF}=49.1 \%(\mathrm{n}=642)$ and $\mathrm{W}=51.2 \%$ to $\mathrm{NF}=9.2 \%(\mathrm{n}=120)$ and $\mathrm{W}=28.3 \%)$, and Trachurus $\mathrm{sp}$. (from $\mathrm{NF}=$ $28.2 \%$ and $\mathrm{W}=35.1 \%$ to $\mathrm{NF}=19.2 \%$ and $\mathrm{W}=46.6 \%$ ) and Longspine snipefish (from $\mathrm{NF}=2.7 \%$ and $\mathrm{W}=0.4 \%$ to $\mathrm{NF}=54.2 \%$ and $\mathrm{W}=$ 17.1\%) increasing it (Fig. 2), although fewer individuals of Trachurus sp. have been found in the stomach contents.

Finally, no variation in the consumption of mesopelagic and epipelagic were found between the different tuna length classes (PERMANOVA: $\mathrm{F}_{2,65}=1.03, \mathrm{r}^{2}=0.03, \mathrm{p}=0.39$ ). The numeric frequency of Atlantic chub mackerel and Trachurus sp. combined was $53.1 \%$ for tunas in the length class $60-80 \mathrm{~cm}, 84.5 \%$ in the length class $80-100 \mathrm{~cm}$, and $76.7 \%$ in the length class $>100 \mathrm{~cm}$.

\subsection{Skipjack tuna diet}

A total of 550 prey individuals were found in 57 stomachs of Skipjack tuna ( 4 empty stomachs), and $98 \%$ of the prey were identified resulting in 8 species, 10 genus and 8 families (Table 1). Teleost fish were the most consumed prey by the Skipjack tuna, which also showed a preference for epipelagic species $(\mathrm{NF}=97 \%)$. The Longspine snipefish was the most consumed species $(\mathrm{NF}=35.8 \%$ and $\mathrm{W}=11.0 \%$ ), followed by Sand smelt Atherina sp. ( $\mathrm{NF}=27.1 \%$ and $\mathrm{W}=13.2 \%$ ). When considering weight, the Atlantic chub mackerel contributed the most to its diet, although it was not the most numerous prey ( $\mathrm{W}=49.5 \%$ and $\mathrm{NF}=14.4 \%$ ). The European pilchard also had an important role in the Skipjack tuna diet ( $\mathrm{NF}=10.4 \%$ and $\mathrm{W}=10.9 \%$ ). Trachurus $\mathrm{sp}$. had a numeric frequency of $4.5 \%$ but contributed with $12.0 \%$ of the total prey weight. No myctophids were found in Skipjack stomachs. The Shannon-Wiener Diversity Index for the Skipjack tuna was $1.59 \pm 0.12(n=57)$.

We found differences among years with the most consumed prey shifting from Sand smelt $(\mathrm{NF}=55.8 \%(\mathrm{n}=138)$ and $\mathrm{W}=18.8 \%)$ and Atlantic chub mackerel (NF $=33.3 \%$ and $\mathrm{W}=78.6 \%$ ) in 2016, to Atlantic chub mackerel $(\mathrm{NF}=10.3 \%(\mathrm{n}=292)$ and $\mathrm{W}=34.2 \%)$, European pilchard $(\mathrm{NF}=19.5 \%$ and $\mathrm{W}=20.3 \%)$ and Longspine snipefish ( $\mathrm{NF}=38.7 \%$ and $\mathrm{W}=12.2 \%)$ in 2017 (Fig. 2). The consumption of Longspine snipefish increased even more in 2018 ( NF $=70.0 \%$ ( $\mathrm{n}=$ $120), \mathrm{FO}=61.5 \%(\mathrm{n}=13)$, and $\mathrm{W}=44.9 \%)$, becoming the most consumed prey in number and weight.

\subsection{Exclusion of bait from diet}

Small differences were found in the relative importance of prey in the diet of these tunas when all bait species with digestion levels I and II were excluded, with the most abundant prey remaining the same. For the Bigeye tuna, Atlantic chub mackerel remained with $\mathrm{NF}=41.1 \%$ $42 \%$ and FO $=69.6 \%-70.8 \%$. Trachurus sp. decreased from NF $=25.7 \%$ to $14.3 \%$ and from $\mathrm{FO}=69.6 \%$ to $50.0 \%$. and Longsnipe snipefish slightly increased from $\mathrm{NF}=10.6 \%$ to $14.3 \%$ and from $\mathrm{FO}=14.5 \%$ to $20.8 \%$ (Supplementary Material, section A.1, Figure A.2). For Skipjack tuna, all bait species varied less than $5 \%$ when including all prey found in the stomachs and when excluding fresh bait species (Supplementary Material, section A.1, Figure A.3). Furthermore, in the stomach contents of Skipjack tunas captured in 2018 (when we had information on the bait used), we found highly digested remains (digestion state IV) of species used as bait and which should only be found undigested if the tunas only ate them as bait (Supplementary Material, section A.1, Table A.2).

\subsection{Mercury concentration comparisons}

Differences among predators in mercury concentrations were also found (ANOVA: $F_{3,82}=22.35, p<0.001$ ). Two distinct groups were observed: Bigeye tuna (blood) and Yellowmouth barracuda (muscle), which had the highest values, and Skipjack tuna (blood) and Longfin yellowtail (muscle) which presented the lowest values (Table 2). Only the Bigeye tuna presented a significant positive correlation between mercury concentration in blood and weight $(\mathrm{r}(18)=0.73, \mathrm{p}=0.0002$ on

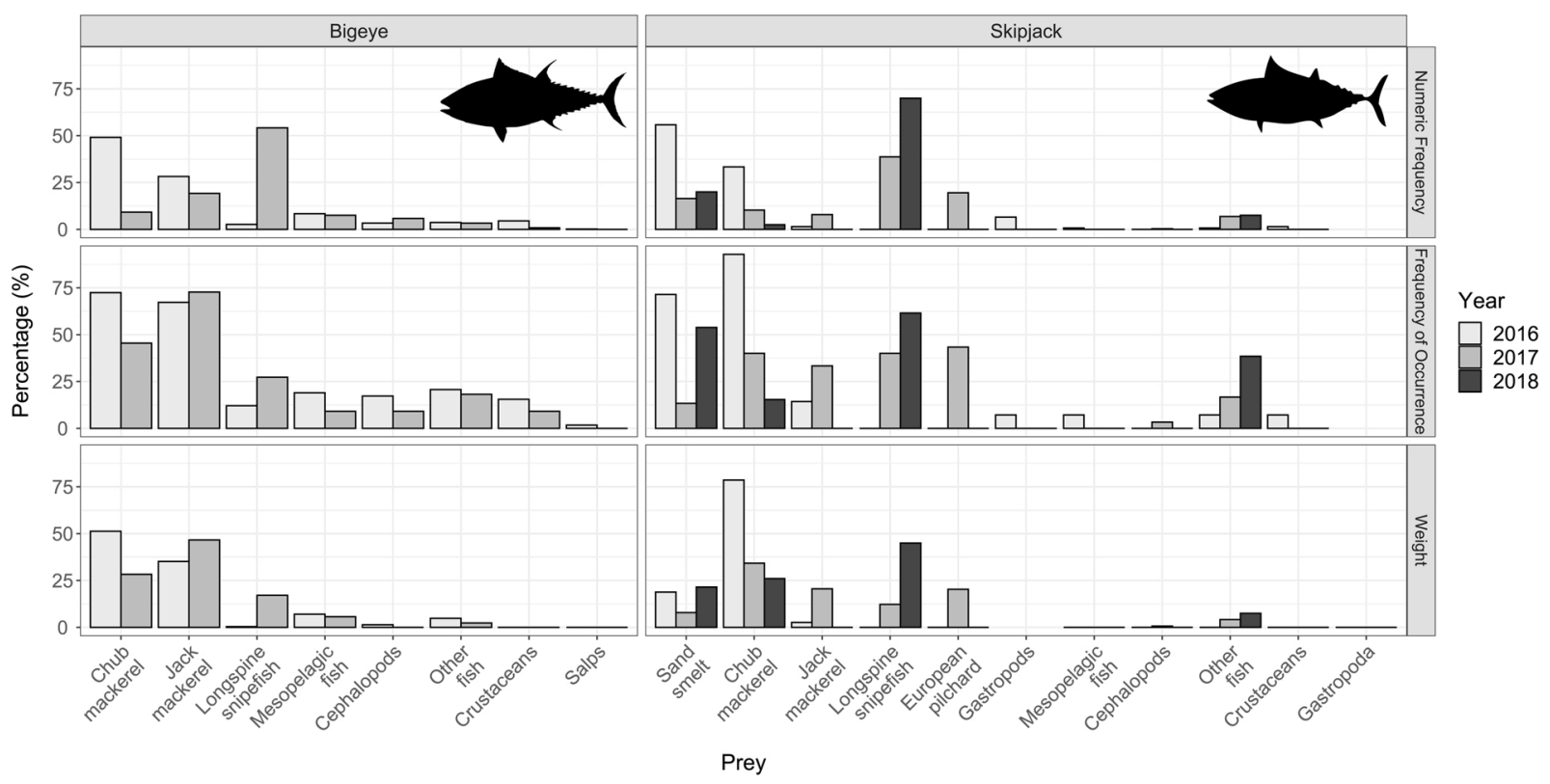

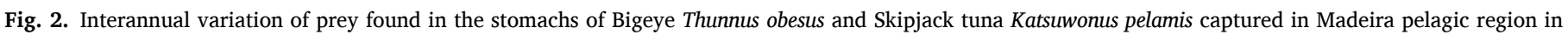
2016-2018. 
Table 2

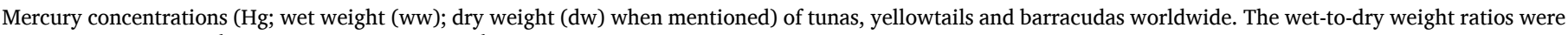
estimated as $1 \mathrm{mg} \mathrm{kg}^{-1}$ wet weight to $3.3 \mathrm{mg} \mathrm{kg}^{-1} \mathrm{dw}$ (Houssard et al., 2019). Values are represented as Mean \pm SD (Min-Max), when possible.

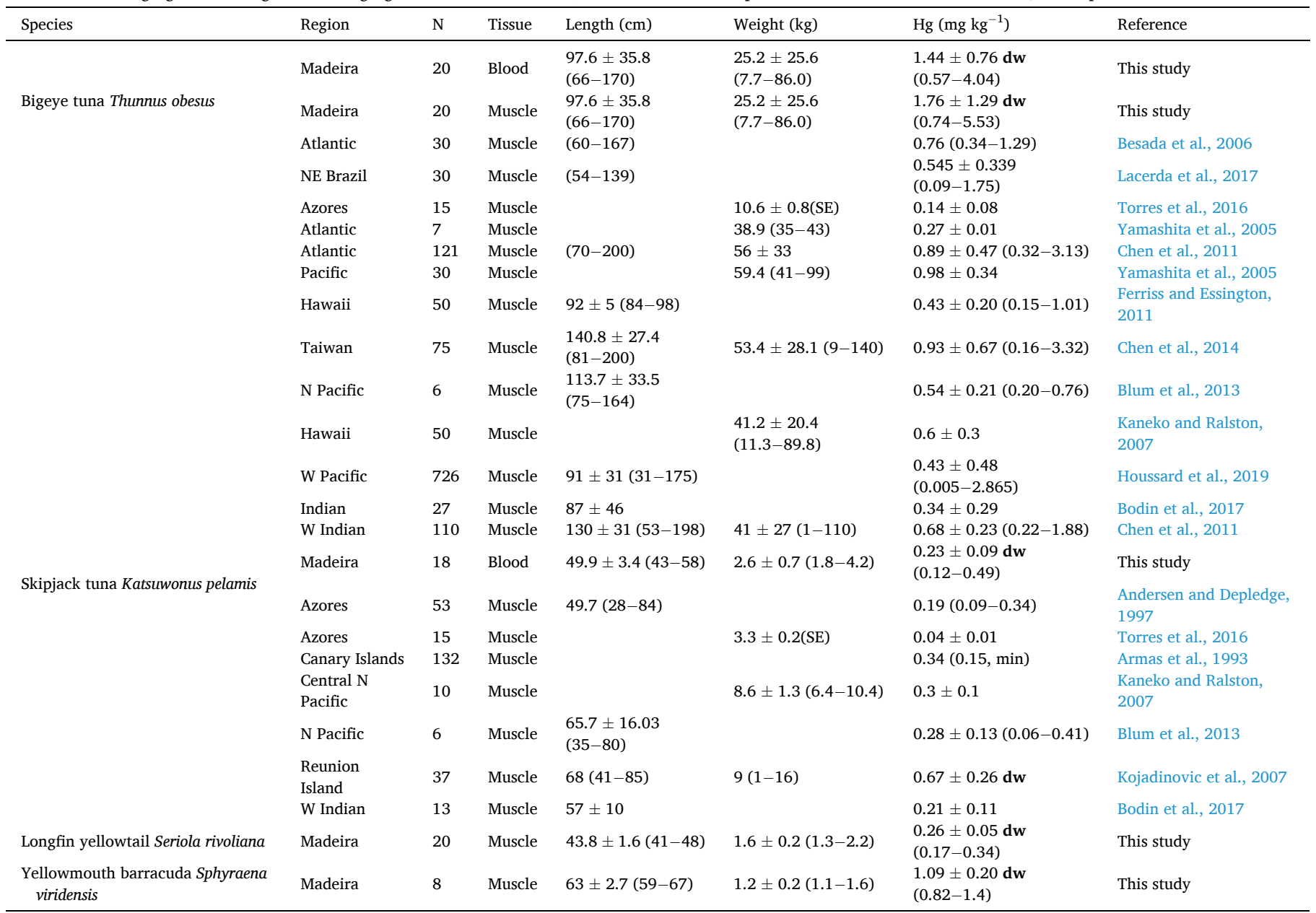

$\log$ transformed data) (Fig. 3); individuals $<100 \mathrm{~cm}$ had $1.08 \pm 0.25 \mathrm{mg}$ $\mathrm{kg}^{-1} \mathrm{dw}(0.57-1.58)$ and individuals $>100 \mathrm{~cm}$ had $2.12 \pm 0.96 \mathrm{mg} \mathrm{kg}^{-1}$ $\mathrm{dw}(1.50-4.04)$.

\section{Discussion}

The use of stomach contents allowed us to document the diet of the

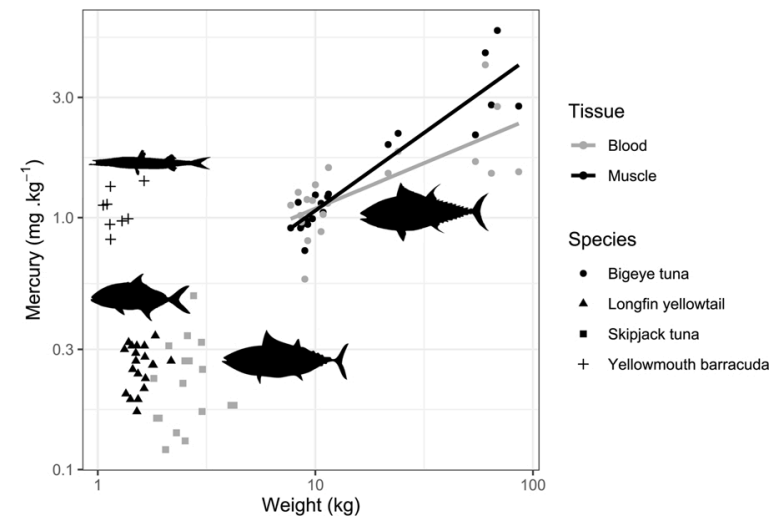

Fig. 3. Mercury concentration (mg. $\mathrm{kg}^{-1}$ dry weight) per fork length of each individual and species, Bigeye tuna Thunnus obesus, Skipjack tuna Katsuwonus pelamis, Yellowmouth barracuda Sphyraena viridensis and Longfin yellowtail Seriola rivoliana. two most fished tuna species, the Bigeye and the Skipjack tuna, in the waters around the archipelago of Madeira. Here, both species presented a diet based on epipelagic organisms, and in the case of the Bigeye tuna complemented by some mesopelagic prey. Some prey species might have been found in the stomachs analysed should our sampling be more intensive for both species. Still, this would not affect our conclusions as their contribution to the diet of these tunas should be small. Furthermore, samples were well spread across the study period, and therefore any strong seasonal signal in the abundance of particular prey would have become apparent in our data. Nonetheless, more studies should be carried out in the region, to allow a more complete description of the prey of both tunas.

\subsection{Diet of the Bigeye and Skipjack tunas}

The diet of the Bigeye tuna captured in the archipelago of Madeira consisted of $92 \%$ weight of epipelagic fish prey ( $\mathrm{NF}=84 \%$ ), in contrast with what was documented in other regions of the Atlantic and Pacific oceans. The published evidence suggests that in both oceans, the diet of Bigeye tuna consists mainly of mesopelagic species, both fish and cephalopods, such as Bramidae, Alepisauridae, Myctophidae, Gempylidae, Paralepididae (eg. Matthews et al., 1977; Moteki et al., 2001; Allain, 2005; Young et al., 2010; Junior et al., 2012) and Ommastrephidae (Logan et al., 2013). These families were scarcely represented ( $\mathrm{NF}=9 \%$ and $\mathrm{W}=7.5 \%$ ), or entirely absent in our study. Besides our study, where Scombridae and Carangidae were the main prey items, 
only one other study performed in the equatorial eastern Pacific in a pole-and-line fishery, found the Bigeye tuna to mostly prey on an epipelagic species (the Buccaneer anchovy Stolephorus buccaneeri) (Hida, 1973). In this region, the bait consisted mostly of 4 epipelagic forage fish which were unimportant as prey items (Hida, 1973).

Bigeye tunas are known to perform daily vertical migrations, descending on average up to $500 \mathrm{~m}$ during the day and ascending to the surface at night, to forage (Matsumoto et al., 2005). However, a study carried out in the Azores showed that Bigeye tunas in this archipelago (mean weight: $36.6 \mathrm{~kg}(20-60 \mathrm{~kg})$ ) do not perform vertical migrations as deep as elsewhere (Arrizabalaga et al., 2008). In that region, tunas remained mostly in the upper $50 \mathrm{~m}$ layer, rarely venturing beyond the $300 \mathrm{~m}$ depth. Arrizabalaga et al. (2008) hypothesized that oceanographic features in the Azores would enhance primary production and concentrate tuna food resources in surface layers, allowing Bigeye tuna to forage on shallower waters. This may suggest that in the Azores, like in Madeira, this tuna concentrates on epipelagic prey. Alternatively, it could be that in the Azores mesopelagic prey are more accessible at shallow depths, which is strongly suggested by their prominence in the diet of surface foragers (Monteiro et al., 1996; Granadeiro et al., 2002). Further studies on the diet and vertical migrations of Bigeye tuna are required for the Madeira and Azores region in order to confirm or contradict any of these hypotheses.

Some studies have suggested that there is an ontogenetic variation in the diet of several species of tunas (eg. Graham et al., 2007; Lacerda et al., 2017), including the Bigeye tuna of which larger individuals feed on higher proportions of mesopelagic species, due to its higher capacity to reach greater depths (Ohshimo et al., 2018). However, in our study, we found no differences in diet between the different size-classes. While we recognize that the larger size-classes $(80-100$ and $>100 \mathrm{~cm})$ were represented by less stomachs ( $n=12$ and 16 , respectively), the predominance of epipelagic species in the diet of these individuals is clear (Atlantic chub mackerel and Trachurus sp., combined NF of $84.5 \%$ and $77 \%$, respectively).

The diet of the Skipjack tuna in the archipelago of Madeira is similar to what has been documented in other regions of the Atlantic, with a predominance of Clupeidae, Scombridae, Carangidae and Serranidae (Postel 1955; Batts, 1972; Dragovich, 1970; Dragovich and Potthoff, 1972). Around the Canary Islands, where pole-and-line technique with live bait (sardine and sand smelt) is also used, the diet of this species is composed mainly of Atlantic chub mackerel (Ramos et al., 1995). In the Pacific, families like Exocoetidae, Engraulidae and reef fish are also part of the skipjack's diet (Alverson, 1963; Hida, 1973; Allain, 2005). In smaller proportions, mesopelagic species, such as Gonostomatidae, Gempylidae and Myctophidae are also part of its diet in the Atlantic and the Pacific oceans (Ahlstrom and Counts, 1958; Dragovich, 1970; Ankenbrandt, 1985). Still, its diet is mostly epipelagic. In our study the only mesopelagic prey found was a Trichiuridae. Crustaceans, such as euphausiids (Ankenbrandt, 1985), stomatopods and megalopa larvae, completed the diet of this tuna in several regions of the Atlantic and Pacific (Alverson, 1963; Dragovich, 1970; Batts, 1972; Dragovich and Potthoff, 1972; Bernard et al., 1985). However, in Madeira, the contribution of crustaceans was negligible ( $\mathrm{NF}=0.4 \%$ and $\mathrm{FO}=1.8 \%$ ).

As opportunistic species, tunas are known to shift their diet between foraging regions but also in response to prey community shifts (Olson et al., 2014). The increase of Longspine snipefish in the diet of the Bigeye and more markedly in the diet of Skipjack tuna follows the trend observed in the diet of the Cory's shearwaters Calonectris borealis in the same oceanic region (Romero et al., 2021), where the authors suggested that a shift happened in the pelagic community of the subtropical northeast Atlantic with an increase of the Longspine snipefish population from 2016 to $2017 / 2018$.

\subsection{The importance of bait in the diet of tunas}

This study considered the issues of bait prevalence on our understanding of Bigeye and Skipjack tuna foraging ecology by excluding fresh bait species and comparing mercury concentrations between predator fishes.

The exclusion of the least digested prey used as bait in Madeira (see eg. Ankenbrandt 1985; Ramos et al., 1995) had minimal impact in the assessment of the diet. Furthermore, highly digested remains of bait species were found in Skipjack tunas, strongly suggesting they are also caught as natural prey. Therefore, the decision to exclude bait species from the diet analysis (rather than discarding only freshly ingested prey) as done in some studies (eg. Ankenbrandt 1985; Ramos et al., 1995), may be excluding prey that are actually important in the diet of these predators.

The analysis of mercury revealed two different groups of predators, one with higher concentrations (Bigeye tuna and Yellowmouth barracuda) and one with lower concentrations (Skipjack tuna and the Longfin yellowtail). Bigeye tuna showed slightly higher $\mathrm{Hg}$ values than the other predators, most likely because the diet of the former includes mesopelagic species, which have high concentrations of mercury (e.g. Monteiro et al., 1996). This is further supported by Choy et al. (2009) which concluded that predators with a mesopelagic diet have higher concentrations of mercury than those with an epipelagic diet. The barracuda also presented higher mercury values despite reportedly having an epipelagic diet, just like the Longfin yellowtail, mainly composed of a variety of schooling epipelagic species, such as Engraulidae, Clupeidae, Scombridae, Carangidae and Sparidae (Allam et al., 1999; Barreiros et al., 2002, 2003; Kalogirou et al., 2012; Manooch and Haimovici, 1983). It is worth mentioning that in the Azores, the main diet of barracudas and yellowtails are Blue jack mackerel and Atlantic chub mackerel (Barreiros et al., 2002, 2003). In the archipelago of Madeira, the yellowtail feeds on European pilchards and Blue jack mackerels (Cavaleiro et al., 2018) while the barracuda feeds on Atlantic chub mackerels (M. Hermida unpubl. data). These species corresponded to the main tuna prey we observed in this study. The reasons for the differences in mercury concentrations between these predator fishes are still unknown, but the fact that $\mathrm{Hg}$ levels in Bigeye tuna are only slightly higher than in barracuda further supports the conclusion that mesopelagics are not an important component of the tuna's diet, or else we would expect a larger difference between these species.

Overall, the mercury concentrations in tissues of tunas presented in this study are lower than in others from the Atlantic, Pacific, and Indian oceans (Table 2), which helps support our conclusion that the diet of the Bigeye tuna around the archipelago is epipelagic. Personal observations onboard tuna fishing vessels have also supported the idea that the proportion of live bait used is very small in comparison with the size of tunas' schools. While intraspecific differences in mercury burdens have also been attributed to the availability of mercury in different foraging regions (Peterson et al., 1973; Ferriss and Essington, 2011; Houssard et al., 2019), the use of conventional diet in our study, indicates that the differences in relation to other areas might be better explained by an epipelagic diet of the Bigeye tuna. Other variables, such as elimination and uptake rate of mercury, may explain the variations observed among species (Peterson et al., 1973). According to Ferriss and Essington (2014), the Skipjack tuna has a higher elimination rate than the Bigeye tuna ( 0.376 and $0.077 \mathrm{y}^{-1}$, respectively) which might explain the lower concentrations. Trudel and Rasmussen (1997) stated that the elimination rate responds negatively to the predator's body mass which could explain the differences between these two species. There are no elimination rates described for barracudas and yellowtails, remaining unclear what are the mechanisms driving the differences in mercury concentrations for barracudas and yellowtails.

The mercury values described in this study for the Bigeye, Skipjack, yellowtail and barracuda were obtained using blood for tunas and muscle tissue for the two other predators. When comparing the mercury values for blood and muscle for the Bigeye tuna, the calculated mean blood-muscle ratio was $1: 1.17$. This suggests that mercury levels in blood and muscle are broadly comparable, but more studies are needed 
to better assess that, as three (out of 20) of the individuals, which were also three of the biggest sampled tunas, presented higher mercury ratios.

The baseline information provided in this study raises new questions on the functioning of the ecosystem of this region. The Bigeye and the Skipjack tuna presented an epipelagic diet in the pelagic region of the archipelago of Madeira, which in the case of the Bigeye tuna suggests a different behaviour than the one often presented by this species. Further studies on the variability in oceanographic variables and its effects on the distribution and abundance of prey, as well as on the vertical movements of tuna in this area are required to understand their behaviour and explain why this mesopelagic predator presents an epipelagic diet in Madeira. The results of this study will allow for more informed decisions on an ecosystem-based fisheries management by considering not only the tuna but also the role they may have in the regional food webs and their interactions with other species.

\section{Authors' contributions}

Joana Romero- Conceptualization, Design and Methodology, Participating in the collection of data, Analysis of the findings, and Drafting and Revising the manuscript. Paulo Catry - Conceptualization, Design and Methodology, Analysis of the findings, Drafting and Revising the manuscript. Margarida Hermida - Methodology, Participating in the collection of data, and Revising the manuscript. Verónica Neves Analysis of the findings and Revising the manuscript. Bárbara Cavaleiro - Participating in the collection of data and Revising the manuscript. José Pedro Granadeiro - Conceptualization, Design and Methodology, Analysis of the findings, Drafting and Revising the manuscript.

\section{Declaration of Competing Interest}

The authors declare that they have no known competing financial interests or personal relationships that could have appeared to influence the work reported in this paper.

\section{Acknowledgements}

This work was supported by Fundação para a Ciência e a Tecnologia (FCT Portugal) through the project OceanWebs (PTDC/MAR-PRO/ 0929/2014) and Seamigrant (PTDC/BIA-ANM/3743/2014), the strategic projects UIDB/04292/2020 and UIDP/04292/2020 granted to MARE, and UIDB/50017/2020 and UIDP/50017/2020 granted to CESAM. PD/BD/127810/2016 was granted to JR by FCT. MH was supported by a postdoctoral grant from Regional Agency for the Development of Research, Technology and Innovation of Madeira (ARDITI), Project M1420-09-5369-FSE-000001. BC was supported by a research grant within the project OceanWebs (PTDC/MAR-PRO/0929/ 2014). Bigeye tuna and barracudas used in this study were acquired by ARDITI through the Oceanic Observatory of Madeira Project (M142001-0145-FEDER-000001-Observatório Oceânico da Madeira-OOM). Skipjack tuna were acquired by the Regional Directorate of Fisheries (DRP) of Madeira, under the framework of the Programa Nacional de Recolha de Dados da Pesca (multiannual Union programme for the collection, management and use of data in the fisheries and aquaculture sectors). The authors are grateful to the Regional Directorate of Fisheries (DRP) of Madeira for their collaboration and support, particularly the Research Service director, João Delgado. Thanks are also due to Filipe Moniz and Carolina Vieira for helping sieving and identifying some of the stomach contents, and Cheila Raposo and Carolina Vieira for performing the mercury analysis.

\section{Appendix A. Supplementary data}

Supplementary material related to this article can be found, in the online version, at doi:https://doi.org/10.1016/j.fishres.2021.105914.

\section{References}

Ahlstrom, E.H., Counts, R.C., 1958. Development and distributions of Vinciguerria lucetia and related species in the eastern Pacific. Fish Bull. 58, 363-416.

Allain, V., 2005. Diet of Large Pelagic Predators of the Western and Central Pacific Ocean. Noumea, New Caledonia, p. 18 pp.

Allam, S.M., Faltas, S.N., Ragheb, E., 1999. Food and feeding habits of barracudas in the Egyptian Mediterranean water off Alexandria. Bull. Nat. Inst. Ocean Fish. 25, 395-410.

Aloncle, H., Delaporte, F., 1974. Données nouvelles sur le germon Thunnus alalunga Bonnaterre 1788 dans le nord-est Atlantique. Rev. Trav. Inst. Pêches marit 37 (4), 475-578.

Alonso, H., Granadeiro, J.P., Waap, S., Xavier, J., Symondson, W.O.C., Ramos, J.A., Catry, P., 2014. An holistic ecological analysis of the diet of Cory's shearwaters using prey morphological characters and DNA barcoding. Mol. Ecol. 23, 3719-3733. https://doi.org/10.1111/mec.12785.

Alonso, H., Granadeiro, J.P., Dias, M.P., Catry, T., Catry, P., 2018. Fine-scale tracking and diet information of a marine predator reveals the origin and contrasting spatial distribution of prey. Prog. Oceanogr. 162, 1-12. https://doi.org/10.1016/j. pocean.2018.02.014.

Alverson, F.G., 1963. The food of yellowfin and skipjack Tunas in the Eastern tropical Pacific Ocean. Inter-Am. Trop. Tuna Comm. 7, 295-396.

Andersen, J.L., Depledge, M.H., 1997. A survey of total mercury and methylmercury in edible Fish and invertebrates from Azorean waters. Mar. Environ. Res. 44, 331-350.

Ankenbrandt, L., 1985. Food habits of bait-caught skipjack tuna, Katsuwonus pelamis, from the southwestern Atlantic Ocean. Fish Bull. 83, 379-393.

Armas, J.D., Diaz, J., Galan, J.M., 1993. Mercury content of the skipjack, Katsuwonus pelamis, off the Canary Islands and adjacent waters. Bol del Inst Esp Oceanogr 9, 9-14.

Arrizabalaga, H., Pereira, J.G., Royer, F., Galuardi, B., Goñi, N., Artetxe, I., Arregi, I., Lutcavage, M., 2008. Bigeye tuna (Thunnus obesus) vertical movements in the Azores Islands determined with pop-up satellite archival tags. Fish Oceanogr. 17, 74-83.

Barreiros, J.P., Santos, R.S., Borba, A.E., 2002. Food habits, schooling and predatory behaviour of the yellowmouth barracuda, Sphyraena viridensis (Perciformes: Sphyraenidae) in the Azores. Cybium 26, 83-88.

Barreiros, J.P., Morato, T., Santos, R.S., Borba, A.E., 2003. Interannual changes in the diet of the almaco jack, Seriola rivoliana, (Perciformes: Carangidae) from the Azores. Cybium 27, 37-40.

Batts, B.S., 1972. Food habits of the skipjack tuna, Katsuwonus pelamis, in North Carolina waters. Chesap Sci. 13, 193-200.

Bernard, H.J., Hedgepeth, J.B., Reilly, S.B., 1985. Stomach contents of albacore, skipjack, and bonito caught off southern California during summer 1983. CalCOFl Rep. 26, $175-182$.

Besada, V., González, J.J., Schultze, F., 2006. Concentraciones de mercurio, cadmio, plomo, arsénico, cobre y zinc en atún blanco, rabil y patudo procedentes del Ocąno Atlántico. Ciencias Mar. 32, 439-445.

Blum, J.D., Popp, B.N., Drazen, J.C., Anela Choy, C., Johnson, M.W., 2013. Methylmercury production below the mixed layer in the North Pacific Ocean. Nat. Geosci. 6, 879-884. https://doi.org/10.1038/ngeo1918.

Bodin, N., Lesperance, D., Albert, R., Hollanda, S., Michaud, P., Degroote, M., Churlaud, C., Bustamante, P., 2017. Chemosphere trace elements in oceanic pelagic communities in the western Indian Ocean. Chemosphere 174, 354-362. https://doi. org/10.1016/j.chemosphere.2017.01.099.

Cavaleiro, B., Hermida, M., Saraiva, A., 2018. Parasites of amberjacks from the archipelago of Madeira, Eastern Atlantic. Dis. Aquat. Organ. 131, 133-142.

Chen, M.H., Teng, P.Y., Chen, C.Y., Hsu, C.C., Teng, P.Y., Chen, C.Y., Organic, C.C.H., 2011. Organic and total mercury levels in bigeye tuna, Thunnus obesus, harvested by Taiwanese fishing vessels in the Atlantic and Indian Oceans, 4(1), pp. 15-21. https://doi.org/10.1080/19393210.2010.535908.

Chen, C.Y., Lai, C.C., Chen, K.S., Hsu, C.C., Hung, C.C., Chen, M.H., 2014. Total and organic mercury concentrations in the muscles of Pacific albacore (Thunnus alalunga) and bigeye tuna (Thunnus obesus). Mar. Pollut. Bull. 85, 606-612. https://doi.org/ 10.1016/j.marpolbul.2014.01.039.

Choy, C.A., Popp, B.N., Kaneko, J.J., Drazen, J.C., 2009. The influence of depth on mercury levels in pelagic fishes and their prey. Proc. Natl. Acad. Sci. 106, 13865-13869. https://doi.org/10.1073/pnas.0900711106.

Clarke, M.R., 1986. A Handbook for the Identification of Cephalopod Beaks. Clarendon Press, Oxford.

da Silva, G.B., Hazin, H.G., Hazin, F.H.V., Vaske Jr., T., 2019. Diet composition of bigeye tuna (Thunnus obesus) and yellowfin tuna (Thunnus albacares) caught on aggregated schools in the western equatorial Atlantic Ocean. J. Appl. Ichthyol. 35, 1111-1118.

Doney, S.C., Ruckelshaus, M., Emmett Duffy, J., Barry, J.P., Chan, F., English, C.A., Galindo, H.M., Grebmeier, J.M., Hollowed, A.B., Knowlton, N., Polovina, J., Rabalais, N.N., Sydeman, W.J., Talley, L.D., 2012. Climate change impacts on Marine ecosystems. Ann. Rev. Mar. Sci. 4, 11-37. https://doi.org/10.1146/annurevmarine-041911-111611.

Dragovich, A., 1970. The food of skipjack and yellowfin tunas in the Atlantic Ocean. Fish Bull. 68, 445-460.

Dragovich, A., Potthoff, T., 1972. Comparative study of food of skipjack and Yellowfin tunas off the coast of West Africa. Fish Bull. 70, 1087-1110.

FAO, 2020. The State of World Fisheries and Aquaculture 2020. Sustainability in action, Rome. https://doi.org/10.4060/ca9229en.

Ferriss, B.E., Essington, T.E., 2011. Regional patterns in mercury and selenium concentrations of yellowfin tuna (thunnus albacares) and bigeye tuna (Thunnus obesus) in the Pacific Ocean. Can. J. Fish. Aquat.Sci. 2056, 2046-2056. https://doi. org/10.1139/F2011-120. 
Ferriss, B.E., Essington, T.E., 2014. Does trophic structure dictate mercury concentrations in top predators? A comparative analysis of pelagic food webs in the Pacific Ocean Ecol. Modell. 278, 18-28. https://doi.org/10.1016/j.ecolmodel.2014.01.029.

Fontes, J., Afonso, P., 2017. Long-term residency and movements of yellowmouth barracuda (Sphyraena viridensis) at a shallow seamount. Mar. Biol. 164, 1-10. https://doi.org/10.1007/s00227-016-3045-1.

Furtado, R., Pereira, M.E., Granadeiro, J.P., Catry, P., 2019. Body feather mercury and arsenic concentrations in five species of seabirds from the Falkland Islands. Mar. Pollut. Bull. 149, 110574 https://doi.org/10.1016/j.marpolbul.2019.110574.

Glaser, S.M., Waechter, K.E., Bransome, N.C., 2015. Through the stomach of a predator: regional patterns of forage in the diet of albacore tuna in the California current system and metrics needed for ecosystem-based management. J. Mar. Syst. 146, 38-49. https://doi.org/10.1016/j.jmarsys.2014.07.019.

Gorni, G.R., 2016. Description of diet of pelagic fish in the southwestern Atlantic, Brazil. Biota Neotrop 13 (1). https://doi.org/10.1590/S1676-06032013000100006.

Gouveia, L., Mejuto, J., 2003. Seasonality and interannual variability in catches of skipjack tuna (katsuwonus pelamis) and bigeye tuna (Thunnus obesus) in the area around the Archipelago of Madeira. Col. Vol. Sci. Pap ICCAT 55, 1853-1867.

Gouveia, L., Amorim, A., Alves, A., Hermida, M., 2019. Updated fishery statistics of tuna species caught off Madeira archipelago. Collect Vol. Sci. Pap ICCAT 75, 2081-2097.

Graham, B.S., Grubbs, D., Holland, K., Popp, B.N., 2007. A rapid ontogenetic shift in the diet of juvenile yellowfin tuna from Hawaii. Mar. Biol. 150, 647-658. https://doi. org/10.1007/s00227-006-0360-y.

Granadeiro, J.P., Silva, M.A., 2000. The use of otoliths and vertebrae in the identification and size-estimation of fish in predator-prey studies. Cybium 24, 383-393.

Granadeiro, J.P., Monteiro, L.R., Silva, M.C., Furness, R.W., 2002. Diet of Common Terns in the Azores, Northeast Atlantic. Waterbirds 25, 149-155. https://doi.org/10.1675/ 1524-4695(2002)025[0149:DOCTIT]2.0.CO;2.

Hermida, M., Delgado, J., 2016. High trophic level and low diversity: would Madeira benefit from fishing down? Mar. Policy 73, 130-137. https://doi.org/10.1016/j. marpol.2016.07.013i.

Hida, T., 1973. Food of Tunas and dolphins (Pisces: Scombridae and Coryphaenidae) with emphasis on the distribution and biology of their prey Stolephorus buccaneeri (Engraulidae). Fish Bull. US 71, 135-143.

Houssard, P., Point, D., Tremblay-Boyer, L., Allain, V., Pethybridge, H., Masbou, J., Ferriss, B.E., Baya, P.A., Lagane, C., Menkes, C.E., Letourneur, Y., Lorrain, A., 2019. A model of mercury distribution in tuna from the Western and Central pacific Ocean: influence of physiology, ecology and environmental factors. Environ. Sci. Technol. 53, 1422-1431. https://doi.org/10.1021/acs.est.8b06058.

Hunter, J., Macewicz, B., Sibert, J., 1986. The spawning frequency of Skipjack tuna, Katsuwonus Pelamis, from the South Pacific. Fish Bull. 84, 895-903.

ICCAT, 2020. International Commission for the Conservation of Atlantic Tunas (accessed 23 March 2020). https://www.iccat.int/en/accesingdb.html.

ISSF, 2017. Status of the World Fisheries for Tuna. February 2017. ISSF Technical Report 2017-02. International Seafood Sustainability Foundation, Washington, D.C., USA.

Junior, T.V., Travassos, P.E., Hazin, F.H.V., Tolotti, M.T., Barbosa, T.M., 2012. Forage fauna in the diet of bigeye tuna (Thunnus obesus) in the Western tropical Atlantic Ocean. Braz. J. Oceanogr. 60, 89-97.

Kalogirou, S., Mittermayer, F., Pihl, L., Wennhage, H., 2012. Feeding ecology of indigenous and non-indigenous fish species within the family Sphyraenidae. J. Fish Biol. 80, 2528-2548. https://doi.org/10.1111/j.1095-8649.2012.03306.x.

Kaneko, J.J., Ralston, N.V.C., 2007. Selenium and Mercury in Pelagic Fish in the Central North Pacific Near Hawaii, pp. 242-254. https://doi.org/10.1007/s12011-0078004-8.

Kojadinovic, J., Potier, M., Le, Corre M., Cosson, R.P., Bustamante, P., 2007. Bioaccumulation of trace elements in pelagic fish from the Western Indian Ocean. Environ. Pollut. 146, 548-566. https://doi.org/10.1016/j.envpol.2006.07.015.

Lacerda, L.D., Goyanna, F., Bezerra, M.F., Silva, G.B., 2017. Mercury concentrations in tuna (Thunnus albacares and Thunnus obesus) from the Brazilian Equatorial Atlantic Ocean. Bull. Environ. Contam. Toxicol. 98, 149-155. https://doi.org/10.1007/ s00128-016-2007-0.

Layman, C.A., Araujo, M.S., Boucek, R., Hammerschlag-Peyer, C.M., Harrison, E., Jud, Z R., Matich, P., Rosenblatt, A.E., Vaudo, J.J., Yeager, L.A., Post, D.M., Bearhop, S., 2012. Applying stable isotopes to examine food-web structure: an overview of analytical tools. Biol. Rev. 87, 545-562. https://doi.org/10.1111/j.1469185X.2011.00208.x.

Lehodey, P., Bertignac, M., Hampton, J., Lewis, A., Picaut, J., 1997. El Niño Southern Oscillation and tuna in the western Pacific. Nature 389, 715-718.

Logan, J.M., Toppin, R., Smith, S., Galuardi, B., Porter, J., Lutcavage, M., 2013. Contribution of cephalopod prey to the diet of large pelagic fish predators in the central North Atlantic Ocean. Deep Res. Part II Top Stud. Oceanogr. 95, 74-82. https://doi.org/10.1016/j.dsr2.2012.06.003.

Lu, C.C., Ickeringill, R., 2002. Cephalopod beak identification and biomass estimation techniques: tools for dietary studies of southern Australian finfishes. Museum Victoria Sci. Reports 6,1-65. https://doi.org/10.24199/j.mvsr.2002.06.
Manooch, C.S.I., Haimovici, M., 1983. Foods of greater amberjack, Seriola dumerili, and Almaco Jack, Seriola rivoliana (Pisces: Carangidae), from the South Atlantic Bight J. Elisha Mitchell Sci. Soc. 99, 1-9.

Matsumoto, T., Miyabe, N., 2002. Preliminary report on the maturity and spawning of bigeye tuna Thunnus obesus in the central Atlantic Ocean. ICCAT Collect Vol. Sci. Pap $54,246-260$.

Matsumoto, T., Saito, H., Miyabe, N., 2005. Swimming behavior of adult bigeye tuna using pop-up tags. Col Vol. Sci. Pap ICCAT 57, 151-170.

Matthews, F.D., Damkaer, D.M., Knapp, L.W., Collette, B.B., 1977. Food of Western North Atlantic Tunas (Thunnus) and Lancetfish (Alepisaurus). NOAA Technical Reports NMFS SSRF-7061, p. 19 pp.

McClellan, D.B., Cummings, N.J., 1997. Preliminary analysis of tag and recapture data of the Greater Amberjack, Seriola dumerili, in the Southeastern United States. Proc. Gulf Caribb. Fish Inst. 49.

Ménard, F., Labrune, C., Shin, Y.J., Asine, A.S., Bard, F.X., 2006. Opportunistic predation in tuna: a size-based approach. Mar. Ecol. Prog. Ser. 323, 223-231. https://doi.org/ 10.3354/meps323223.

Monteiro, L.R., Ramos, J.A., Furness, R.W., Delnevo, A.J., 1996. Movements, morphology, breeding, molt, diet and feeding of seabirds in the azores. Colon Waterbirds 19, 82-97.

Moteki, M., Arai, M., Tsuchiya, K., Okamoto, H., 2001. Composition of piscine prey in the diet of large pelagic fish E tropic Pacific Ocean. Fish Sci. 67, 1063-1074.

Ohshimo, S., Hiraoka, Y., Sato, T., Nakatsuka, S., 2018. Feeding habits of bigeye tuna (Thunnus obesus) in the North Pacific from 2011 to 2013. Mar. Freshw. Res. 69, 585-606. https://doi.org/10.1071/MF17058.

Olson, R.J., Duffy, L.M., Kuhnert, P.M., Galván-Magaña, F., Bocanegra-Castillo, N., Alatorre-Ramírez, V., 2014. Decadal diet shift in yellowfin tuna Thunnus albacares suggests broad-scale food web changes in the eastern tropical Pacific Ocean. Mar. Ecol. Prog. Ser. 497, 157-178. https://doi.org/10.3354/meps10609.

Palumbi, S.R., 1996. Nucleic Acids II: the Polymerase Chain Reaction. Molecular Systematics, Hillis DM, pp. 205-247.

Peterson, C.L., Klawe, W.L., Sharp, G.D., 1973. Mercury in Tunas: a review. Fish Bull. 71, 603-613.

Ramos, A.G., Lorenzo, J.M., Pajuelo, J.G., 1995. Food habits of bait-caught skipjack tuna, Katsuwonus pelamis, off the Canary Islands. Sci. Mar. 59, 365-369.

Reynolds, S.J., Hughes, B.J., Wearn, C.P., Dickey, R.C., Brown, J., Weber, N.L., Weber, S. B., Paiva, V.H., Ramos, J.A., 2019. Long-term dietary shift and population decline of a pelagic seabird-A health check on the tropical Atlantic? Glob. Change Biol. 25, 1383-1394. https://doi.org/10.1111/gcb.14560.

Romero, J., Catry, P., Alonso, H., Granadeiro, J.P., 2021. Seabird diet analysis suggests sudden shift in the pelagic communities of the subtropical Northeast Atlantic. Mar. Environ. Res. 165, 105232.

Schaefer, K.M., Fuller, D.W., Block, B.A., 2009. Tagging and Tracking of Marine Animals with Electronic Devices. Tagging and Tracking of Marine Animals with Electronic Devices, pp. 121-144.

Storelli, M.M., Giacominelli-Stuffler, R., Storelli, A., Marcotrigiano, G.O., 2005. Accumulation of mercury, cadmium, lead and arsenic in swordfish and bluefin tuna from the Mediterranean Sea: a comparative study. Mar. Pollut. Bull. 50, 1004-1007.

Team, R.C., 2020. R: A Language and Environment for Statistical Computing. R Foundation for Statistical Computing, Vienna, Austria. http://www.r-project.org/.

Teffer, A.K., Staudinger, M.D., Taylor, D.L., Juanes, F., 2014. Trophic influences on mercury accumulation in top pelagic predators from offshore New England waters of the northwest atlantic ocean. Mar. Environ. Res. 101, 124-134. https://doi.org/ 10.1016/j.marenvres.2014.09.008.

Torres, P., Rodrigues, A., Soares, L., Garcia, P., 2016. Metal concentrations in Two commercial tuna species from an active volcanic region in the mid-Atlantic Ocean. Arch. Environ. Contam. Toxicol. 70, 341-347. https://doi.org/10.3354/meps11707.

Trudel, M., Rasmussen, J.B., 1997. Modeling the elimination of mercury by fish. Environ. Sci. Technol. 31, 1716-1722.

Varela, J.L., Cañavate, J.P., Medina, A., Mourente, G., 2019. Inter-regional variation in feeding patterns of skipjack tuna (Katsuwonus pelamis) inferred from stomach content, stable isotope and fatty acid analyses. Mar. Environ. Res. 152.

Voegborlo, R.B., Adimado, A.A., Ephraim, J.H., 2007. Total mercury distribution in different tissues of frigate tuna (Auxis thazard thazard) from the atlantic coastal waters of Ghana, Gulf of Guinea. Environ. Monit. Assess. 132, 503-508. https://doi. org/10.1007/s10661-006-9552-7.

Whitehead, P.J.P., Bauchot, M.-L., Hureau, J.-C., Nielsen, J., Tortonese, E., 1989. Fishes of the North-eastern Atlantic and the Mediterranean. UNESCO, Paris.

Yamashita, Y., Omura, Y., Okazaki, E., 2005. Total mercury and methylmercury levels in commercially important fishes in Japan. Fish Sci. 71, 1029-1035.

Young, J.W., Lansdell, M.J., Campbell, R.A., Cooper, S.P., Juanes, F., Guest, M.A., 2010. Feeding ecology and niche segregation in oceanic top predators off eastern Australia. Mar. Biol. 157, 2347-2368. https://doi.org/10.1007/s00227-010-1500-y.

Zhu, G., Xu, L., Zhou, Y., Chen, X., 2009. Growth and mortality rates of bigeye tuna Thunnus obesus (Perciformes: Scombridae) in the central Atlantic Ocean. Rev. Biol. Trop. 57, 79-88. 